\title{
M. L. URQUHART
}

\author{
DAVID ELLIOTT
}

(Received 21 November 1967)

To assess the mathematical work of the late M. L. Urquhart is, paradoxically, both easy and extremely difficult. It is easy, in that he never published a mathematical paper in any of the journals. Thus one does not have to read a large volume of published work. On the other hand, Urquhart was far from being mathematically inactive, but he communicated his ideas verbally to his associates. At this point of time it is well nigh impossible to recall all the ideas that he discussed so freely during his lifetime. Conversations have long since been forgotten and ideas are now only vaguely remembered. Consequently any objective assessment of Urquhart's mathematical work is very difficult.

Malcolm Livingstone Urquhart was born on Cape Barren Island, Tasmania, in 1902. When he was young, his family moved to Hobart, and there Urquhart attended the Hutchins School. After leaving school, he worked for a while as a surveyor and railway engineer for the Tasmanian State Railways. The work of surveying aroused his interest in precision instruments, and throughout his life he was always fascinated by the mathematics of such instruments.

He entered the University of Tasmania as an Engineering student in 1923. At the end of the first year he was awarded the Thomas Normoyle Prize for the greatest proficiency in the 1st year Engineering examinations, but half way through his second year he changed from an Engineering to a Science course, because of his growing interest in Physics. He graduated with a Bachelor of Science degree in 1926, having majored in Physics and Applied Mathematics. After graduation, Urquhart worked for a short period as a Demonstrator in the Physics Department of the University of Tasmania, and then went as a Physicist to the Defence Department Laboratories at Maribyrnong, Victoria.

In 1928, Urquhart left Australia for England, and went to Bristol University to study Theoretical Physics under Professor Lennard-Jones. At this time, a considerable amount of interest was being generated by the then new subject of Wave Mechanics. For a Ph.D. thesis, Urquhart was set the problem of investigating the binding energy of the helium molecular ion. All the simpler systems, the hydrogen atom, the helium atom, the hydrogen 
molecular ion and the hydrogen molecule had by that time been investigated, and the helium molecular ion was the next obvious system to be analysed by the methods of wave mechanics. By the use of perturbation methods, Urquhart successfully solved this problem, and obtained a state with small positive binding energy. With his thesis nearly completed, he went on a holiday to the Continent, and there he met a party of Italian Physicists. During conversation with them, he discovered that one of their colleagues (E. Majorana) had also successfully completed this problem and furthermore, had recently had his results published in an Italian journal. Urquhart did not obtain his Ph.D. degree. One can now only conjecture as to the effect this must have had on him. Later in his life, he flatly refused to publish any of his mathematical results. Whether or not this was a consequence of his disappointment over his Ph.D. thesis, no one now seems to know.

During his four years at Bristol University, as well as working on his thesis and giving some lectures on Quantum Mechanics to post-graduate students, he translated from German into English a book on wave mechanics by Professor J. Frenkel. This translation had a curious history, and I shall quote (with minor amendments) from the Preface of Frenkel's 'Wave Mechanics, Elementary Theory'.

'Two years ago Mr. Urquhart of the University of Bristol started, with the approval of Professor Lennard-Jones, a translation of my German book Einführung in die Wellenmechanik. This translation reached me at the beginning of 1931 while I was lecturing on Wave Mechanics at the University of Minnesota (Minneapolis, U.S.A.). It was intended that, after a slight revision and correction, it should be published by the Oxford Press. But during the three years that had elapsed since the appearance of the German original, my views on the subject had greatly developed, and in some respects (especially with regard to the analogy between matter and light) had been substantially modified. As a result I became dissatisfied with my German version and started to write what is practically a new book, thus wholly undoing the work of Mr. Urquhart. I wish to record here how much I regret this, and also to thank Mr. Urquhart for the additional work he undertook of revising the English of my new version.'

In August 1932, Urquhart returned to Australia as a Lecturer in the Mathematics Department of Melbourne University. He still had hopes of writing another $\mathrm{Ph} . \mathrm{D}$. thesis, but the pressure of his lecturing and examination work prevented this. The latter was not a trivial chore, for each year he had to spend the entire long vacation marking several thousand scripts from the mathematical examinations of the Senior Technical Colleges in Victoria. Doubtless, it was this work that contributed at least in part to Urquhart's great interest in mathematical education at both the secondary 
and tertiary levels. For it is as a lecturer to countless University undergraduates, that Urquhart will be most remembered. He was a fine teacher and was very fond of the Socratic method. Students in his lectures were encouraged (and expected) to think constructively of the problems he placed before them. He had a wonderful facility for stripping all the nonessentials from a mathematical problem, so that he could consider it in its simplest and most fundamental terms. Students were expected to follow his example.

During the period 1932-1944, that Urquhart was at Melbourne University, the Mathematics Department under the late Professor Cherry, produced some outstanding students who have later reached considerable eminence in the mathematical world. From the honours graduates of this period one finds two Fellows of the Royal Society of London, G. K. Batchelor and R. H. Dalitz, Professors at Cambridge and Oxford respectively. H. C. Corben and G. S. Watson are now Professors in overseas universities, whilst within Australia, one finds E. R. Love, G. Newstead, A. F. Pillow, J. P. O. Silberstein, R. C. T. Smith, K. C. Westfold and the late H. C. Levey attaining professorial rank. Urquhart's contribution to the lecturing of the Mathematics Department during those years was not inconsiderable. One of his former students, Professor E. R. Love, describes Urquhart at that time as follows:

'He came to us from Britain, and in every way he seemed 'different': different in dress, different in the things he talked about, different in the ways he conducted lectures, different in the ways he spent his time. Whether he set out to be different or not, he had considerable impact on us, and left a quite distinctive image in our memories. He surprised us by expecting us to consider a certain theorem in analytical dynamics 'beautiful'. He astonished us by describing how he had had the task of deducing, from a survey of the ruins of an aeroplane, how the crash had come about. He rampaged about commercialism and meaningless slogans in advertising. He speculated on the virtues of hexagonal town planning. Occasionally these excursions took place in lecture hours, and at other times he would button-hole you in the cavernous corridors of Old Arts and argue anything from religion to the tides. His mind was restless and critical, and he did everything to stimulate us into thinking.'

Urquhart would probably have stayed at Melbourne University for the remainder of his academic career had he not contracted tuberculosis. In 1943, he returned to Hobart to recover from this illness, and was unable to do much work for 4 years. In 1947, he joined the Mathematics Department of the University of Tasmania as a Lecturer. In 1952, he was promoted to Senior Lecturer, and on the 1st January 1966, just seven weeks before he 
died, to Reader. In Tasmania, as in Melbourne, Urquhart made a major contribution to the Department's lecturing. In one year, because of staffing difficulties, he gave all the lectures in Applied Mathematics. At one time or another during his lecturing career, he also gave lectures to first, second and third year classes in Pure Mathematics, as well as fourth year lectures in Geometry and Relativity. The only subject in which he was not prepared to lecture was Statistics.

Until the end of his life, Urquhart retained his enthusiasm for mathematics. He was a founder member of the Australian Mathematical Society, and missed only one of the Society's Annual Conferences, when he was on study leave in England in 1961. In Tasmania he helped to start the local Mathematical Association, and was its first President, guiding the Association firmly through its early years.

Outside of his mathematical interest, he had a great love of the Australian bush and in his younger days did a considerable amount of bush walking. He was an authority on South-West Tasmania, a rugged region of lakes, mountains and forests which, in his early days, was largely unexplored. Here he undertook long trips of discovery, either on his own or with a small group of men.

Urquhart was essentially a shy man, but with those he knew well, he would talk for hours on a wide variety of subjects. For his interests ranged widely, and since he had a highly original mind, his conversation was invariably stimulating. He frequently held minority views, but these he was always ready to defend with much skill and enthusiasm.

Throughout his life, Urquhart had a great love of Geometry, and used his knowledge of this subject to explain subjects as diverse as the expanding earth theory and the design of lenses. Perhaps it is not inappropriate to conclude this brief essay with a statement of his 'most elementary theorem of Euclidean Geometry'. I recall him coming into my office one day and asking me what I thought was the most elementary theorem of Euclidean Geometry. Since it was obvious that whatever I said was going to be incorrect, he rapidly gave the following theorem:

'Let $A C$ and $A E$ be two straight lines which intersect at $A$. Let $B$ be a point on $A C, D$ a point on $A E$, and suppose that $B E$ and $C D$ intersect at $F$. If $A B+B F=A D+D F$, then $A C+C F=A E+E F$ '

Urquhart considered this to be the 'most elementary theorem', since it involves only the concepts of straight line and distance. The proof of this theorem by purely geometrical methods is not elementary. Urquhart discovered this result when considering some of the fundamental concepts of the theory of special relativity.

In the second half of $\mathbf{1 9 6 5}$, Urquhart was found to be suffering from 
an inoperable cancer. With the courage that he had demonstrated in his previous illness, he was able to complete his University duties that year. He died on February 23rd 1966, and is survived by his wife and daughter.

\section{Acknowledgement}

I would like to thank Professor E. R. Love of Melbourne University who provided me with a list of Melbourne Mathematics graduates for the period 1932-1944, and also allowed me to quote from a letter he wrote to me on M. L. Urquhart.

Thanks are also due to Messrs. B. J. Gardner and G. T. Kohl of the University of Tasmania; the former for painstakingly sorting all the mathematical papers left by M. L. Urquhart, the latter for carefully reading through them. 